\title{
Figures, Maps, and Tables
}

\section{Figures}

1 “Prize Question," 191119

2 Family of Sir Richard Strachey, ca. 189325

3 August Bebel (1840-1913) 39

4 Lower chamber of the Saxon Landtag, 190548

5 Social Democratic Reichstag deputies, 188950

6 Richard Hartmann's machine works factory in Chemnitz, 1868/9 71

7 Leipzig high treason trial, 187275

8 "A Safe Hideout for Editors," 190386

9 The Dissatisfied One, 1877105

10 August Bebel and Friedrich Wilhelm Fritzsche, 1878118

11 "We Hoot at the Law!" 1878123

12 "Full Steam Ahead!" 1892132

13 "Leipzig's Little State of Siege," 1881137

14 "Election Agitators," 1884143

15 Social Democratic identification card, 1885155

16 The Arrest of the Propagandist, 1880s 172

17 Police dissolution of a workers' election rally in Berlin, 1890193

18 The Strike, 1886198

19 "Dropping the Pilot," 1890214

20 "Workers' May Day Demonstration: Exodus to Loschwitz," 1890218

21 August Bebel and Paul Singer celebrate May Day, 1890220

22 “The Social Democrat Is Coming!!!" 1892233

23 "Homage to Freedom," 1893249

24 “The Ruthless August," 1903288 
25 August Bebel addressing the Reichstag, 1905292

26 "From Bismarck to Buelow," 1907303

27 A family of home workers in the Saxon Ore Mountains, 1909322

28 Proportion of Landtag voters and ballots cast, Saxony, 1909341

29 Berlin police prepare for a suffrage demonstration, 1910350

30 Undercover agents of the Berlin police, 1913356

\section{Maps}

1 The German Empire and the Kingdom of Saxony, 1871-1918 xiv

2 Reichstag constituencies in the Kingdom of Saxony, 1867-1918 63

\section{Tables}

1 Social Democracy and Reichstag Elections in the German Empire, 1871-1912 42

2 Social Democracy and Reichstag Elections in the Kingdom of Saxony, 1871-1912 45

3 Landtag Elections in the Kingdom of Saxony, 1869-1893 47

4 Landtag Elections in the Kingdom of Saxony, 1869-1895 47

5 Reichstag Elections in Saxony and the Reich, 1871 and 187478

6 Reichstag Elections in Saxony and the Reich, 1874 and $1877 \quad 100$

7 Reichstag Elections in Saxony and the Reich, 1877 and 1878117

8 Reichstag Elections in Saxony and the Reich, 1881144

9 Reichstag Elections in Saxony and the Reich, 1884 and 1887189

10 Reichstag Elections in Saxony and the Reich, 1887 and 1890210

11 Reichstag Elections in Saxony and the Reich, 1893246

12 Reichstag Elections in Saxony and the Reich, 1898 and 1903286

13 Landtag Voters and Ballots Cast, Saxony, 1909340

14 Proportion of Landtag Voters and Ballots Cast, Saxony, 1909340

15 Reichstag Elections in Saxony and the Reich, 1907 and 1912368 